\title{
Stable isotope ratios and contaminant concentrations in a sewage-distorted food web
}

\author{
Robert B. Spies ${ }^{1}$, Harold Kruger ${ }^{2}$, Robert Ireland ${ }^{1}$, David W. Rice, $\mathrm{Jr}^{1}$ \\ ${ }^{1}$ Environmental Sciences Division, Lawrence Livermore National Laboratory, University of California, Box 5507, Livermore, \\ California 94550, USA \\ ${ }^{2}$ Kruger Laboratories, 24 Blackstone Street, Cambridge, Massachusetts 02139, USA
}

\begin{abstract}
Concentrations of selected neutral organic contaminants and stable isotope ratios of carbon, nitrogen and deuterium/hydrogen in invertebrates and fish were compared from near a large, $60 \mathrm{~m}$ deep municipal waste outfall near Los Angeles, California, where waste has a measurable influence on the structure of the marine food web, and from a reference area off Santa Barbara, California. Objectives were to investigate (1) the degree of utilization of sewage organic matter in the food web, especially by 3 species of fish, (2) differences in contaminant accumulation between these benthophagous fish and (3) the behavior of organic contaminants relative to each other and to organic matter through several trophic levels. Isotopically lighter carbon and nitrogen and higher concentrations of most chlorinated hydrocarbons were found in tissues of organisms from near the outfall. On the basis of the $\delta^{13} \mathrm{C}$ and $\delta^{15} \mathrm{~N}$ of the fishes, the estimated contribution of nitrogen and carbon from sewage was about 15 to $20 \%$ of their requirements for these elements. The $\delta^{13} \mathrm{C}$ and $\delta^{15} \mathrm{~N}$ values increased in the fishes in the order of Microstomus pacificus, Citharichthys sordidus and Zaniolepis latipinnis. The Cs/K ratio of the latter species was also significantly higher than the former 2 species, also indicating its higher trophic position. C. sordidus had the highest wet-weight concentrations of chlorinated hydrocarbons and phthalic acid esters; intermediate concentrations of these compounds were found in $Z$. latipinnis and the lowest concentrations were found in $M$. pacificus. Concentrations of chlorinated hydrocarbons on a lipid-weight basis changed this order so that it more closely resembled the trophic structure revealed by the stable isotope ratio and $\mathrm{Cs} / \mathrm{K}$ ratio data. Increases of both $\Sigma \mathrm{DDT}$ and Aroclor 1254, from deposit-feeding invertebrates through fish, were evident in foodwebs of the outfall and reference areas as positive correlations with $\delta^{13} \mathrm{C}$. A large degree of correlation was evident between contaminants in $Z$. latipinnis but not in the other 2 fish species. These correlations were apparently not a function of liver lipid concentration, but the strengths of the correlations were dependent on the similarities of $\log \mathrm{K}_{\mathrm{ow}}$ values of the correlated compounds.
\end{abstract}

\section{INTRODUCTION}

Over $2 \times 10^{5}$ metric tons of sewage particulate matter are discharged into the Southern California Bight each year (Schafer 1984). Associated with these particles are a variety of xenobiotic contaminants, such as chlorinated hydrocarbons, aromatic hydrocarbons, phthalic acid esters, heterocycles and chlorophenols (Young \& Gossett 1980, Eganhouse \& Kaplan 1982, Gossett et al. 1982, Schafer 1984). The sewage particles are about $60 \%$ organic matter, compared to ca $2 \%$ in endogenous marine particulate matter (Sweeney \& Kaplan 1980).

As a result of particulate matter settling, sediments have accumulated at the rate of 0.6 to $1.7 \mathrm{~g} \mathrm{~cm}^{-2} \mathrm{yr}^{-1}$ (dry) during the 1970's near the Los Angeles County
Joint Water Pollution Control Plant (JWPCP) outfall (Stull et al. 1986a). This deposition of particles with a high organic content has had a marked effect on the food web, changing microbial and invertebrate populations in accordance with effects expected from organic enrichment (Pearson \& Rosenberg 1978, Stanley et al. 1978, Stull et al. 1986b). The general effect evident in the invertebrate populations was a stimulation of selected species of deposit-feeding infauna, especially polychaetes, while crustaceans, particularly amphipods, became less numerous (Smith \& Green 1976, Word \& Striplin 1980).

Changes in populations of benthophagous fish were also noted near the JWPCP outfall during the 1970's (Cross et al. 1985; see Spies 1984 for review). One species in particular, the Dover sole (American appella- 
tion) Microstomus pacificus, sustained very large populations in the outfall area, while others, such as the yellow chin sculpin Icelinus quadriseriatus and the longspine combfish Zaniolepis latipinnis appeared to be reduced in numbers compared to nearby areas (Allen 1977, Word \& Mearns 1978). There is now evidence that the ability of some fishes to feed on infaunal populations, particularly polychaetes, and the inability of other fishes to switch from a diet of crustaceans to other food items, contributed to these altered fish abundances (Cross et al. 1985).

Sewage particulate matter has stable isotope ratios for nitrogen and sulfur lighter than those of marine particulate matter in the Southern California Bight (Sweeney \& Kaplan 1980, Sweeney et al. 1980). Carbon isotope ratios are heavier and the ratio of deuterium to hydrogen is greater in sewage than in marine particulate organic matter (Table 1). However, the sediment

Table 1. Relative abundances of stable isotopes in marine and sewage particulate matter All values in \%

\begin{tabular}{|lccc|}
\hline Isotope ratio & Marine & Sewage & Difference \\
\hline$\delta^{13} \mathrm{C}$ & -19 to -21 & -16.5 & 2.5 to 4.5 \\
$\delta \mathrm{D}$ & -105 to $-139^{\mathrm{b}}$ & -52 & 57 to 87 \\
$\delta^{15} \mathrm{~N}$ & 8 to $12^{\mathrm{C}}$ & 1.8 & -6.2 to -10.2 \\
a Monthly composite sample of & JWPCP final primary \\
effluent particulate matter, November 1983 \\
b Stuermer et al. 1978; this is a value for humic acids and \\
kerogen \\
c See Wada et al. 1975, Sweeney et al. 1980, Sweeney \& \\
Kaplan 1980, Venkatesan et al. 1980 \\
\hline
\end{tabular}

carbon in the vicinity of a large outfall is isotopically lighter $(-23.5 \%)$ than sewage particulate matter (Myers 1974). As the organic matter in sediments near the outfall is utilized by the marine food web it would be expected that these stable isotope signatures would undergo small changes with each trophic level (DeNiro \& Epstein 1978, 1980, Estep \& Dabrowski 1980). For example, laboratory experiments indicate that the stable carbon isotope ratio, $\delta^{13} \mathrm{C}$, would be expected to change only about $0.7 \%$ per trophic step (DeNiro \& Epstein 1978), while Rau et al. (1983) reported trophic step factors of about $1.4 \%$ in Southern California marine ecosystems. Such changes can be used to interpret trophic structures of food webs (McConnaughey \& McRoy $1979 a$, b). Nitrogen isotope changes are usually somewhat larger and vary more from species to species (DeNiro \& Epstein 1980, Minagawa \& Wada 1984). An earlier study from an area receiving wastewaters showed that Microstomus pacificus and the ridgeback prawn Sicyonia ingentis were isotopically lighter in carbon and nitrogen and isotopically heavier in deuterium/hydrogen ( $\delta D$ ) than those collected in a reference area near Ventura, California (Rau et al. 1981).

In addition to the stable isotope ratios, the elemental ratios of cesium to potassium have also been used to interpret foodweb structure (Young 1970). In this case the heavier element, rather than the heavier isotope, has a longer residence time in organisms and, hence in the foodweb, resulting in greater $\mathrm{Cs} / \mathrm{K}$ in higher trophic levels.

Changes in the treatment of sewage to be discharged from the Los Angeles County's JWPCP outfall have resulted in decreasing rates of particulate matter deposition in sediments of the Palos Verdes Shelf as well as lesser concentrations of major contaminants in the surface few $\mathrm{cm}$ of sediment (Stull et al. 1986a). However, the inventories of metals and trace organic contaminants show that this portion of the Palos Verdes Shelf is a significant repository of potentially biologically available contaminants.

The existence of unique isotope signatures and high degree of contamination provided an opportunity for the simultaneous study of the transfer of sewage-derived organic material and contaminants to deposit-feeding invertebrates and eventually to benthophagous fish. Such a study would reveal (1) the degree to which coupling was occurring between the benthos and certain fish populations, (2) differences in contaminant accumulation between fish species with disparate diets and (3) the behavior of organic contaminants relative to each other and to organic matter through several trophic levels. Here we report the results of such a study utilizing deposit-feeding infauna, invertebrate predators and 3 species of fish: the longspine combfish Zaniolepis latipinnis, the Dover sole Microstomus pacificus, and the Pacific sanddab Citharichthys sordidus. These organisms were analysed for $\mathrm{DDDT}$, polychlorinated biphenyls (PCBs), phthalic acid esters; the ratios of stable isotopes of carbon $\left(\delta^{13} \mathrm{C}\right)$, nitrogen $\left(\delta^{15} N\right)$ and deuterium/hydrogen $(\delta D)$; and $\mathrm{Cs} / \mathrm{K}$.

\section{METHODS AND MATERIALS}

Sites. The JWPCP outfall, located near Los Angeles, California, USA, discharges an average of $1.35 \times 10^{9}$ $\mathrm{l} \mathrm{d}^{-1}$ of effluent and the annual mass-emission rate of all chlorinated hydrocarbons is ca $1100 \mathrm{~kg}$ (Young \& Gossett 1980). Large amounts of DDT-type compounds (ca 200 metric tons) remain in the outfall area sediments from past discharges (Young et al. 1980). The outfall is located $2 \mathrm{~km}$ offshore at a depth of $60 \mathrm{~m}$. The area off Santa Barbara, California on the $60 \mathrm{~m}$ isobath served as a reference site. Sewage discharges in Santa Barbara County to the northern part of the Southern 
California Bight are only a fraction of the volume discharged from the Los Angeles area outfalls and largescale disturbances of the bottom communities have not been reported (SCCWRP 1973). In particular, Santa Barbara County discharges ca $0.072 \times 10^{9} \mathrm{ld}^{-1}$ of treated sewage effluent as compared to $2.7 \times 10^{9} \mathrm{Id}^{-1}$ from Los Angeles County (pers. comm., H. Schafer, SCCWRP, Long Beach, CA)

Species selection. The fish species were selected to represent different trophic habits and a range of response to sewage. Microstomus pacificus exhibits very high densities in the JWPCP outfall area relative to other sites at the same depth in the Southern California Bight (Word \& Mearns 1978). This species also feeds extensively on infaunal polychaetes in outfall sediments (Allen 1982, Cross et al. 1985). In fact, in 1983 trawl-captured specimens near the outfall area had stomach contents consisting almost entirely of the opportunistic polychaete Tharyx tesselata (pers. obs., R. Spies). Thus, M. pacificus would appear to be one trophic level above detritivores. Citharichthys sordicus exhibits a less clear response to sewage, since in one study it appeared to be less dense near the outfall than in other areas (Word \& Mearns 1978), while in another study it seemed to exhibit somewhat higher densities and tended to feed on polychaetes close to the outfall (Cross et al. 1985). The food of $C$. sordidus is dependent on the size of fish; smaller individuals eat glycerid polychaetes and other benthic and pelagic organisms, while larger individuals feed almost exclusively on pelagic organisms (Allen 1982). Thus C. sordidus appears to be between 1 and 2 trophic levels above detritivores. Zaniolepis latipinnis appears to be less dense in sewage-affected areas (Cross et al. 1985); it is benthophagous and piscivorous - feeding on crustaceans, polychaetes and sanddabs (= genus Citharichthys) (Allen 1982). Thus, this species also apparently has a higher trophic level than $M$. pacificus and probably higher than $C$. sordidus, since it feeds on this latter species. In general little is known of the movement of these species in the Southern California Bight. Some portion of the population of $M$. pacificus moves to deeper water in winter (Cross 1985), but there is little evidence for extensive lateral movement of any of these species. The differences in chemical composition of the species collected here indicates that movement is not sufficient to obscure site differences. Fish from near the JWPCP outfall carry a clear isotopic and chemical signature that indicates they had been in the vicinity for some time.

The invertebrate species used were those that occurred in high enough densities in the grab samples to obtain enough tissue for the analyses and that were likely to be utilized by benthophagous fish (Allen 1982). Glycerid polychaetes were included as they are eaten by Citharichthys sordidus; the cirratulid polychaete Tharyx tesselata was also included, as it forms the diet of Microstomus pacificus (see above). An effort was made to include other detritivores and predators based on the trophic analysis of polychaete families (Fauchald \& Jumars 1979).

Sampling. Sampling was carried out on August 16 and 17, 1983, around the JWPCP outfall and on September 20, 1983, near Santa Barbara (Fig. 1). The time difference between the 2 samplings was due to limitations of ship scheduling and there is no reason to expect that differences in measured parameters are due to this factor. Fish were captured in 5 or more 10 min otter trawls and invertebrates in 3 to 5 Van Veen grab samples (Fig. 1). Fish were segregated by trawl sample and species in stainless steel trays, wrapped in aluminum foil and refrigerated immediately after collection. Invertebrates were separated from sediments by sieving on a $0.5 \mathrm{~mm}$ Nytex screen using water dipped from the ocean in stainless steel buckets. Twenty of each fish species were weighed and then dissected within $10 \mathrm{~h}$ of collection. The livers, gonads (when large enough) and 2 flesh samples were then removed by clean techniques, weighed, and frozen on dry ice. The alimentary canals were also removed and preserved in formalin for casual inspection of stomach contents. Benthic invertebrates were kept alive in glass containers with cold seawater $\left(13^{\circ} \mathrm{C}\right)$ from the sampling sites. They were allowed to void their guts for $10 \mathrm{~h}$ and external sediment was removed with a camel hair brush before preservation by freezing. Composite samples were made for each taxon using only specimens without visible sediments in their guts. In addition a filtered $(10 \mu \mathrm{m})$ and oven-dried $\left(60^{\circ} \mathrm{C}\right)$ composite sample of JWPCP final advanced primary effluent for October 1983 was prepared for analysis.

Stable isotope analyses. Flesh samples of fish were prepared for analysis by oven drying at $60^{\circ} \mathrm{C}$ and whole invertebrates were dried with anhydrous $\mathrm{Na}_{2} \mathrm{SO}_{4}$. Analyses were carried out at Kruger Laboratories, Cambridge, Massachusetts, USA, by combusting at least $10 \mathrm{mg}$ of material in the presence of $\mathrm{O}_{2}$, followed by condensation of water of combustion, which was collected for determination of $\delta \mathrm{D}$. Combustions were carried out in closed tubes in the presence of $\mathrm{CuO}_{2}$. A single combustion was used to obtain all the analyses of a tissue. Differential low temperature distillation of gases was used to separate oxides of nitrogen for determination of ${ }^{15} \mathrm{~N} /{ }^{14} \mathrm{~N}$, and $\mathrm{CO}_{2}$ for determination of ${ }^{13} \mathrm{C}^{12} \mathrm{C}$. Isotope ratios were determined in model VG903 and VG602D quadrapole mass spectrometers. Shifts were calculated as $\delta \mathrm{R}=\left[\mathrm{R}_{\text {unknown }} \times\right.$ $\mathrm{R}_{\text {standard }}-1$ ] 1000 , where $\mathrm{R}={ }^{13} \mathrm{C}:{ }^{12} \mathrm{C},{ }^{15} \mathrm{~N}:{ }^{14} \mathrm{~N}$ or $\mathrm{D}: \mathrm{H}$ and the standards were Peedee Belemnite (carbon), atmospheric air (nitrogen) and Standard Mean Ocean 


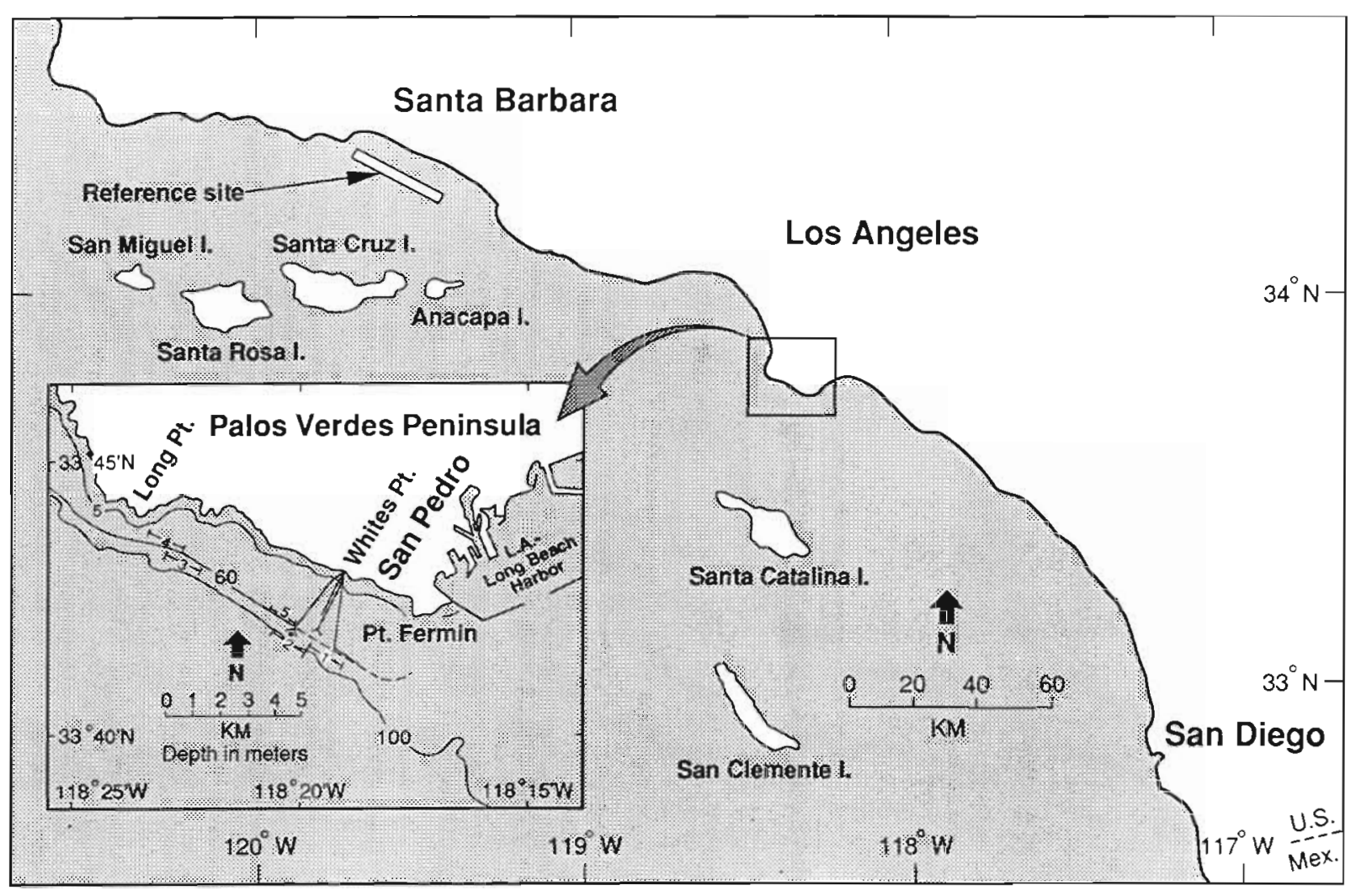

Fig. 1. Sampling locations near Los Angeles and off Santa Barbara, California. Trawls are indicated by straight lines and are numbered. The grab sample is indicated by a filled circle between the ends of the westernmost line of the JWPCP outfall

Water (deuterium: hydrogen). Precision for organic matter samples in this system, based on many analyses of replicates and standards is $\pm 2.0 \%$ for $\delta \mathrm{D} ; \pm 0.1$ to $0.2 \%$ for $\delta^{13} \mathrm{C}$ and \pm 0.2 to $0.3 \%$ for $\delta^{15} \mathrm{~N}$

Several samples of Microstomus pacificus flesh which appeared particularly oily were reanalysed for all isotopes after lipids were extracted with refluxing toluene, as lipids are known to be often isotopically lighter than other major classes of compounds (Estep \& Hoering 1980), and lipid content can vary significantly among individuals.

Cesium and potassium analyses. As an independent measure of trophic level, the $\mathrm{Cs} / \mathrm{K}$ of each species was measured (Young 1970). These elements were measured in the dorsolateral muscle of 5 specimens of each fish species from the JWPCP outfall collections. Potassium concentrations in ashed samples were determined by atomic absorption spectrometry by Soil Control Laboratories, Watsonville, Califormia. A National Bureau of Standards (NBS) orchard leaves standard analysed at the same time gave values within $1 \%$ of the expected concentrations of potassium. Cesium was measured in ashed samples by neutron-activation analysis by Nuclear Energy Services, Raleigh, N. Carolina, USA. Analysis of NBS orchard and citrus leaves standards produced values within $5 \%$ of the expected concentration of cesium. Potassium measurements were not corrected for chemical recovery before calculating $\mathrm{Cs} / \mathrm{K}$ on a wet-weight basis. Likewise cesium concentrations were not corrected for possible losses during ashing.

Organic contaminant analyses. We generally followed the methods of Ozretich \& Schroeder (1986) for analysis of neutral organic contaminants in marine samples. In preparation for extraction, invertebrates and fish livers were thawed at room temperature in glass beakers. Tissues were diced or torn into small pieces with stainless steel spatulas. Approximately $5 \mathrm{~g}$ of $\mathrm{Na}_{2} \mathrm{SO}_{4}$ (analytical grade, was heated to $600^{\circ} \mathrm{C}$ for 12 to $24 \mathrm{~h}$ ) was added for every $1 \mathrm{~g}$ of tissue to remove unbound water. For contaminant extraction, 15 to $30 \mathrm{ml}$ of spectrographic-grade acetonitrile (Burdick and Jackson $\left.{ }^{(}\right)$was added to each sample. Two $\mathrm{ml}$ of an internal standard consisting of $1.0 \mathrm{mg} \mathrm{ml}^{-1}$ of $4,4^{\prime}$ dibromobiphenyl was added to each sample. The sample was then ground into a slurry with the stainless steel head of a Brinkman Polytron ${ }^{\circledR}$ homogenizer. This mixture was allowed to settle and the extractant was decanted. The extraction was carried out twice more, with centrifugation following the last extraction. 
The extracts from fish livers were made up to $100 \mathrm{ml}$ in a volumetric flask, a $1 \mathrm{ml}$ subsample was removed for the gravimetric determination of lipid, and the remainder was stored for 12 to $24 \mathrm{~h}$ at $4{ }^{\circ} \mathrm{C}$. A variable amount of the extract, usually 15 to $25 \mathrm{ml}$, was removed for cleanup and analysis. Sample cleanup was performed with disposable solid-phase extraction columns (Baker ${ }^{\sqrt{8}}$ ), using $\mathrm{C}_{18}$ and $\mathrm{NH}_{2}$ as the solid phase absorbents. The $\mathrm{C}_{18}$ columns were conditioned with acidified (pH2) methanol $(6 \mathrm{ml})$ followed by a methanol rinse. A column/reservoir ( $6 \mathrm{ml}$ capacity) was added above and a $\mathrm{NH}_{2}$ column below. Approximately $0.2 \mathrm{~g}$ of anhydrous $\mathrm{Na}_{2} \mathrm{SO}_{4}$ (cleaned as described above) was added to the filtration column to ensure that all water would be removed from the extractant. The serial 3-column assembly was then mounted on a suction manifold and conditioned with a $10 \mathrm{ml}$ rinse of acetonitrile. The samples were reduced to $4 \mathrm{ml}$ by rotary evaporation before being introduced to the columns. They were slowly pulled through the columns under vacuum. This was followed by 2 sample $(0.5 \mathrm{ml})$ and 2 column $(1 \mathrm{ml})$ rinses. Usually 4 or 5 samples and a blank would be processed simultaneously on the manifold. Cleaned-up samples were reduced to a final volume of $0.1 \mathrm{ml}$ by a combination of rotary evaporation and a stream of cold, pure nitrogen. This chemical procedure routinely produced good blanks with only a few phthalic acid esters as contaminants. In all cases concentrations of these compounds reported in tissues were more than 10 times the amounts in blanks. For 1 to $2 \mathrm{~g}$ liver samples, sufficient biogenic materials were removed to allow clear resolution of a variety of organic contaminants by gas chromatography.

A Hewlett-Packard 5880 gas chromatograph, equipped with an electron-capture detector (ECD), capillary injector and a fused-silica capillary column (SE 54) and run on a mixture of $90 \%$ argon and $10 \%$ methane carrier gas, was used for resolving organic contaminants. Compounds were identified on the basis of retention time of EPA-supplied authentic standards and some mass spectrometry (Hewlett Packard, 5985). Response factors were empirically determined for each compound by injecting known amounts of authentic standards. Raw data from each chromatographic run were stored in a Hewlett Packard 3354 automated laboratory data system. Concentrations of each contaminant were calculated based on the original sample weight, portion of extractant used, injection volume, response factor and recovery of the internal standard.

Because some interconversion of DDT-type compounds appeared to be occurring during chromatography of our standards, we have reported only $\Sigma D D T$ value: the sum of ortho, meta and para-isomers of DDT, DDD and DDE. Quantification of PCB's as Aroclor mixtures (1242, 1254 and 1260) was based on compar- ing the height of a single peak in each sample to a corresponding unique peak in the reference mixtures for each Aroclor.

Statistical analyses. All data were log-transformed or arcsin-transformed before statistical analyses. Statistical analyses were carried out on a VAX computer using a statistical analysis package (SAS 1985).

\section{RESULTS}

\section{Stable isotope ratios of sewage particles and invertebrates}

In Table 1 the stable isotope abundances of the sewage particles from the JWPCP composite sample are compared with values from the literature for marine particulate matter elsewhere in the Southern California Bight. The JWPCP outfall sediments are isotopically lighter in carbon $\left(\delta^{13} \mathrm{C}=-23.5\right.$; Meyers 1974) than endogenous marine particulate matter and sewage particulate matter is heavier in deuterium relative to hydrogen and lighter in nitrogen than the marine particulate matter. The reason for the discrepancy in carbon isotope ratios between sewage particulate matter and outfall sediments has not been demonstrated, but may be related to microbial processing

In Table 2 stable isotope abundances of infaunal invertebrates from Santa Barbara and the JWPCP outfall are compared. Although statistical analysis of the carbon shifts is not possible because of single composite samples for each taxon, it can be seen that JWPCP invertebrates are consistently isotopically lighter for carbon than those from the Santa Barbara reference area. The amount of material for determination of $\delta D$ and $\delta^{15} \mathrm{~N}$ was limited, but glycerid polychaetes were isotopically lighter in N at JWPCP than at the reference area.

\section{Comparison of stable isotope ratios between fish species and sites}

The stable isotope ratios of each species from the JWPCP outfall area and the Santa Barbara reference station are compared in Table 3 and Fig. 2. Significant site and species differences are evident for $\delta^{13} \mathrm{C}$ and $\delta^{15} \mathrm{~N}$; species but no site differences occurred for $\delta \mathrm{D}$. For $\delta^{13} \mathrm{C}$ and $\delta^{13} \mathrm{~N}$, Microstomus pacificus was the most dissimilar of the 3 species, having isotope values consistently lighter for $\delta^{13} \mathrm{C}$ (by about $0.9 \%$ ) and $\delta^{15} \mathrm{~N}$ (by about $1.7 \%$ ) at both sites, relative to the other species. Zaniolepis latipinnis and Citharichthys sordidus did not differ significantly from each other for either carbon or nitrogen isotope ratios. Z. latipinnis was significantly 
Table 2. Comparison of relative abundances of stable isotopes in invertebrates between taxa and sites. SB: Santa Barbara, JWPCP: Los Angeles County Outfall

\begin{tabular}{|c|c|c|c|c|}
\hline Taxon & Site & $\delta^{13} \mathrm{C}$ & $\delta^{15} \mathrm{~N}$ & $\delta D$ \\
\hline \multicolumn{5}{|l|}{ Glycerid } \\
\hline \multirow[t]{3}{*}{ polychaetes } & $\mathrm{SB}$ & -17.6 & 10.9 & -91 \\
\hline & JWPCP & -18.7 & 7.5 & - \\
\hline & $\Delta^{a}$ & -1.5 & -3.4 & - \\
\hline \multicolumn{5}{|l|}{ Lumbrinerid } \\
\hline \multirow[t]{3}{*}{ polychaetes } & $\mathrm{SB}$ & -17.6 & 11.9 & -103 \\
\hline & JWPCP & -19.7 & - & \\
\hline & $\Delta$ & -2.1 & & \\
\hline \multicolumn{5}{|l|}{ Pectinaria } \\
\hline \multirow[t]{3}{*}{ californiensis } & SB & -18.0 & - & - \\
\hline & JWPCP & -21.6 & - & - \\
\hline & $\Delta$ & -3.0 & & \\
\hline \multicolumn{5}{|l|}{ Tharyx } \\
\hline \multirow[t]{3}{*}{ tesselata } & SB & $-17.0^{\mathrm{b}}$ & - & - \\
\hline & JWPCP & -19.6 & & \\
\hline & $\Delta$ & -2.6 & - & - \\
\hline \multicolumn{5}{|l|}{ Misc. } \\
\hline \multirow[t]{3}{*}{ polychaetes } & SB & -18.2 & - & - \\
\hline & JWPCP & -20.0 & - & - \\
\hline & $\Delta$ & -1.8 & - & \\
\hline \multicolumn{5}{|l|}{ Nemerteans } \\
\hline & SB & -16.6 & - & -100 \\
\hline & JWPCP & -24.0 & 0.1 & - \\
\hline & $\Delta$ & -7.4 & - & - \\
\hline \multicolumn{5}{|c|}{ a Difference in isotope values between sites, in \%o } \\
\hline \multicolumn{5}{|c|}{$\begin{array}{l}\text { b Value from Spies \& DesMarais (1983), in } 15 \mathrm{~m} \text { of water } \\
\text { near Campus Point, Santa Barbara Channel (comparison } \\
\text { station for petroleum-seep study) }\end{array}$} \\
\hline
\end{tabular}

isotopically heavier for deuterium/hydrogen, but the other 2 species were similar.

There were consistent differences in isotope ratios of nitrogen and carbon between the 3 species that are evident at both sites (Fig. 2). Such differences are consistent with increasing trophic level from Microstomus pacificus to Citharichthys sordidus to Zaniolepis latipinnis. In fact among the 60 measured JWPCP outfall fish belonging to these 3 species, there was a highly significant correlation between these isotope ratios ( $r=$ $0.52 ; F=21 ; p>0.0001$ )

Rau et al. (1981) described a positive correlation between $\delta^{15} \mathrm{~N}$ and body weight in Microstomus pacificus from the area of the JWPCP outfall. We found a nearly identical relationship (Fig. 3a). However a significant negative relation between these 2 parameters was found for Zaniolepis latipinnis (Fig. 3b); no significant relation was found for Citharichthys sordidus.

\section{$\mathrm{Cs} / \mathrm{K}$ in fish}

Significant differences in Cs concentrations and in $\mathrm{Cs} / \mathrm{K}$ occurred between species (Table 4). Zaniolepis latipinnis had significantly higher values for these measures than the other 2 species, which did not differ from one another. Based on the arguments and evidence presented by Young (1970 and references therein) that $\mathrm{Cs}$ is retained longer in organisms than potassium and therefore the $\mathrm{Cs} / \mathrm{K}$ increases with trophic level, these data indicate that $Z$. latipinnis occupies a higher trophic level than the other 2 fish species. The ranking of the species by $\mathrm{Cs} / \mathrm{K}$ thus results in the same relative trophic relationships as with the carbon and nitrogen stable isotope data.

\section{Contributions of sewage-derived carbon and nitrogen in benthophagous fish}

The proportions of sewage-derived carbon and nitrogen can be estimated in organisms from the outfall area based on differences in their stable isotope ratios between the outfall and reference areas and the stable isotope ratios of the sewage particulate matter. The mixing model takes the form:

$$
1.0\left(\delta \mathrm{R}_{o o}\right)=X\left(\delta \mathrm{R}_{\mathrm{sp}}+\mathrm{b}\right)+(1-\mathrm{X})\left(\delta \mathrm{R}_{\mathrm{ro}}\right)
$$

where $\delta R_{o 0}=$ relative stable isotope abundances in organisms from outfall; $\delta R_{s p}=$ relative stable isotope abundances in sediments or sewage particulate matter; $\delta R_{\text {ro }}=$ relative stable isotope abundances in organisms from reference area; $b=$ trophic step factor (this applied in the case of carbon based on the $+0.7 \%$ per trophic level step reported by DeNiro \& Epstein 1978); and $\mathrm{X}=$ proportion of sewage-derived element $\mathrm{R}$ in organism.

The results of solving this equation for $\mathrm{X}$ using $\delta^{13} \mathrm{C}$ and $\delta^{15} \mathrm{~N}$ in the 3 species of fish are given in Table 5. Based on the stable isotope ratio and $\mathrm{Cs} / \mathrm{K}$ differences between species we assumed 2 trophic steps between carbon in outfall sediments and $\mathrm{Mi}$ crostomus pacificus and Citharichthys sordidus and 3 steps for Zaniolepis latipinnis. We did not correct for a trophic effect with nitrogen as this can vary widely between species. It can be seen that, except for the carbon value for $M$. pacificus, the calculated values fall within a range from 14 to $22 \%$ using either element. The difference in the contribution of sewage to the diet of $M$. pacificus observed when the present data are used $(7 \%)$ and those of Rau et al. (1981) are used $(33 \%)$ are almost entirely due to different isotope values obtained for the control samples in the 2 studies, $-16.6 \%$ and $-17.8 \%$ respectively. The intraspecific carbon and nitrogen values are also remarkably similar for $Z$. latipinnis (22 and $16 \%$ ) and C. sordidus (16 and $14 \%$ ). The estimated proportions of sewage carbon and nitrogen for this latter species are less than for the other species, indicating less 
Table 3. Comparison of stable isotope ratios between fish species and sites. (A) Cell and marginal means ( \pm SD); (B) ANOVA table

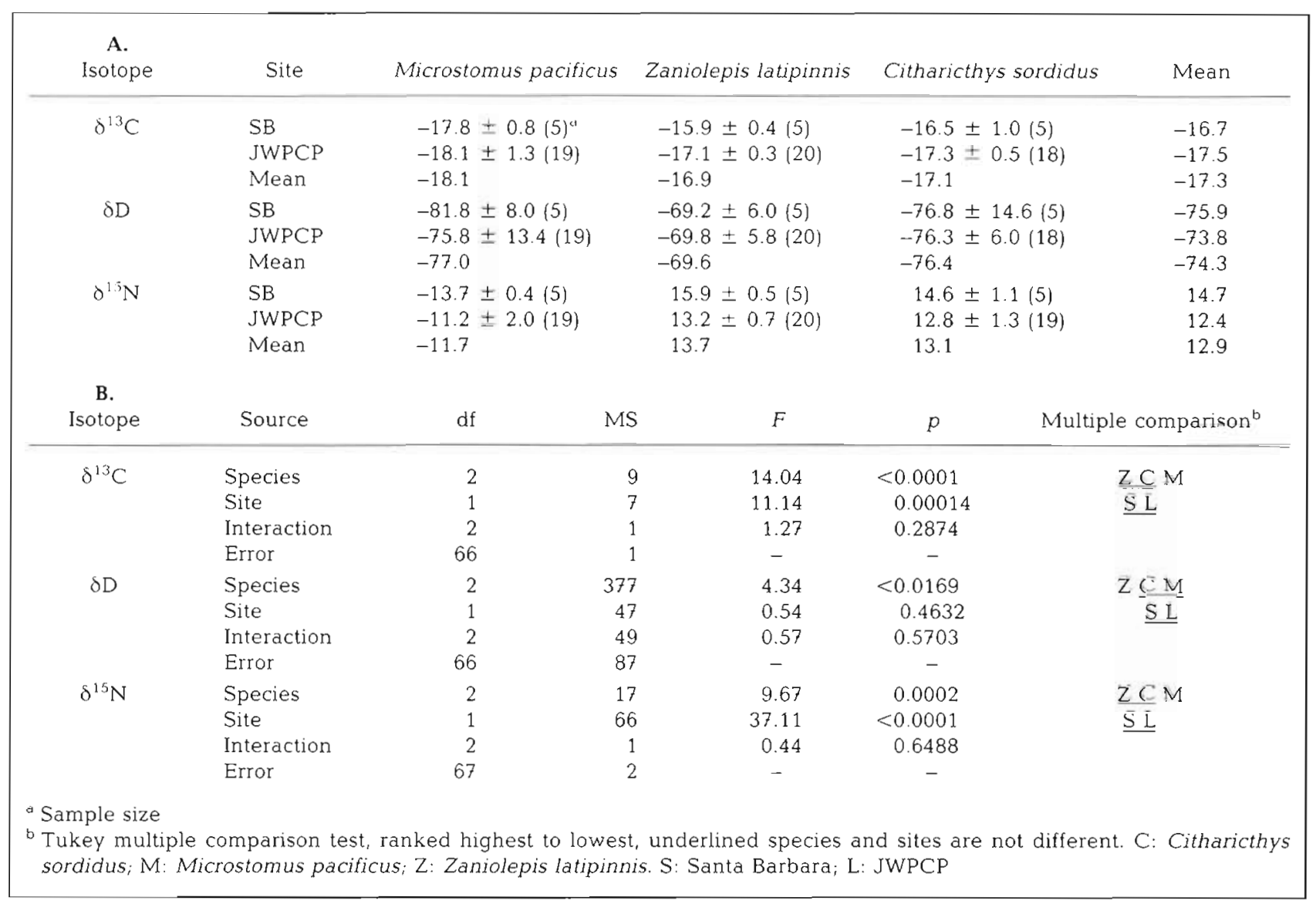

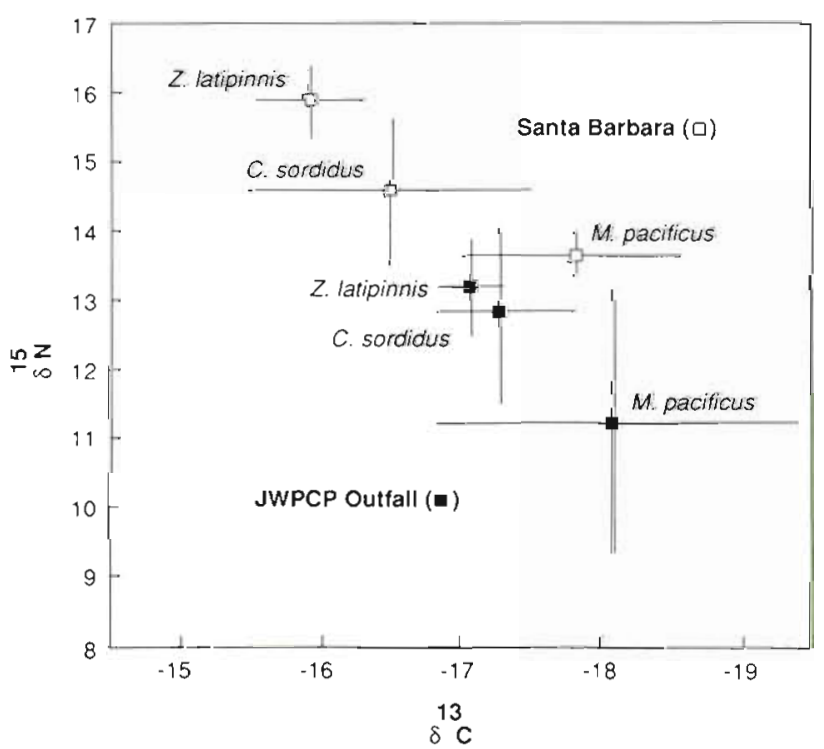

Fig. 2. Microstomus pacificus, Citharichthys sordidus, Zaniolepis latipinnis. Plot of $\delta^{13} \mathrm{C}$ and $\delta^{15} \mathrm{~N}$ in 3 species of fish from the JWPCP outfall and near Santa Barbara. Lengths of crossed lines indicate standard deviations of the means dependence on sewage-derived organic matter in its diet. The calculated proportions of carbon and nitrogen from sewage in $Z$. latipinnis indicate that although this species may not be abundant in the outfall area it derives substantial amounts of its carbon and nitrogen from sewage. The estimated proportions of nitrogen utilized by each species are conservative as inclusion of trophic step factors for nitrogen in the mixing model would have increased the estimated amount of sewage-derived nitrogen.

\section{Contaminant concentrations in invertebrates}

Concentrations of organic contaminants in composite samples of invertebrates are given in Table 6. For all contaminants and for all taxa, except glycerid polychaetes, JWPCP invertebrates have higher concentrations. The Aroclor 1254 and 1260 concentrations in glycerid polychaetes are higher than expected in the one composite sample from Santa Barbara; the reason for this is not known. 


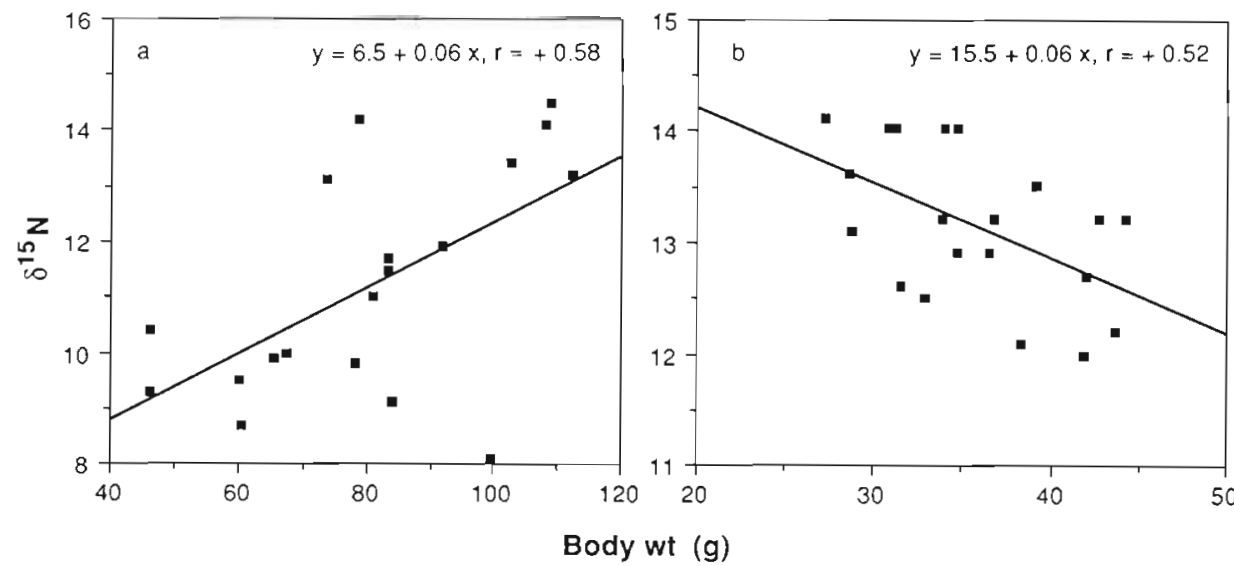

Fig, 3. Relationships between $\delta^{15} \mathrm{~N}$ and body weight in 2 species of fish from the JWPCP outfall area: (a) Microstomus pacificus; (b) Zaniolepis latipinnis

Table 4. Mean cesium and potassium concentrations in the muscle tissue of 3 species of benthophagous fish from the JWPCP outfall. Concentrations $\left( \pm S D\right.$ ) are in $\mu \mathrm{g} \mathrm{kg}^{-1}$ wet wt

\begin{tabular}{|c|c|c|c|c|c|c|}
\hline & Microstomus pacificus & Citharichthys sordidus & Zaniolepis latipinnis & F & $p$ & $\mathrm{MCT}^{\mathrm{a}}$ \\
\hline Cesium & $10.8 \pm 2.7$ & $12.1 \pm 2.7$ & $22.4 \pm 10.9$ & 7.3 & 0.009 & $\underline{M C Z}$ \\
\hline Potassium & $2.1 \pm 0.32$ & $2.4 \pm 0.63$ & $2.2 \pm 2.2$ & 0.36 & 0.70 & $\overline{\mathrm{MCZ}}$ \\
\hline $\mathrm{Cs} / \mathrm{K}$ & $5.1 \pm 1.2$ & $5.2 \pm 1.2$ & $10.2 \pm 4.8$ & 7.0 & 0.01 & $\mathrm{MCZ}$ \\
\hline
\end{tabular}

Table 5. Estimates of the proportions of sewage-derived carbon and nitrogen in three species of benthophagous fish collected near the JWPCP outfall

\begin{tabular}{|lcc|}
\hline & Carbon & Nitrogen \\
\hline Microstomus pacificus & $0.07^{\mathrm{a}},(0.33)^{\mathrm{b}}$ & 0.21 \\
Zaniolepis latipinnis & 0.22 & 0.18 \\
Citharichthys sordidus & 0.16 & 0.14 \\
& \\
a Calculated from values obtained in our study \\
${ }^{\mathrm{b} C a l c u l a t e d}$ from values in Rau et al. (1981) \\
\hline
\end{tabular}

\section{Contaminant concentrations in fish livers}

The mean contaminant concentrations in the livers of the 3 fish species are given in Table 7 . As expected, the concentrations of SDDT were much greater for the JWPCP fish. The high concentrations of Aroclor 1242 in Microstomus pacificus and of Aroclor 1260 in all 3 species from Santa Barbara were somewhat surprising; the Santa Barbara collections had concentrations equal to or greater than those from the JWPCP outfall area. The higher EDDT and Aroclor 1254 concentrations in fish from JWPCP and the higher Aroclor 1260 concentrations in Santa Barbara fish were significant. There were significant interspecific differences in concentrations of Aroclor 1254 but not $\Sigma$ DDT.
Normalization of the chlorinated hydrocarbons to lipid content affected some of the species differences in the outfall collections. No significant species differences were observed for EDDT or Aroclor 1260, although in both cases the lowest concentrations occurred in Microstomus pacificus. The mean concentration of Aroclor 1242 in Citharichthys sordidus $(6.0 \pm 4.5 \mu \mathrm{g}$ $\mathrm{g}^{-1}$ lipid) was significantly less than in either Zaniolepis latipinnis $\left(12.1 \pm 8.0 \mu \mathrm{g} \mathrm{g}^{-1}\right.$ lipid) or $M$. pacificus $\left(11.0 \pm 3.5 \mu \mathrm{g} \mathrm{g}^{-1}\right.$ lipid). For Arocior $1254 \mathrm{Z}$. latipinnis (76.6 $\pm 63 \mu \mathrm{g} \mathrm{g}^{-1}$ lipid) was not significantly different from $C$. sordidus (66.5 $\pm 87 \mu \mathrm{g} \mathrm{g}^{-1}$ lipid), but was different from $M$. pacificus $\left(22.7 \pm 9.7 \mu \mathrm{g} \mathrm{g}^{-1}\right.$ lipid)

\section{Relationships among stable isotope ratios and contaminant concentrations in outfall fish}

If the concentrations of the 2 chlorinated hydrocarbons that were significantly elevated in the JWPCP outfall fish livers, EDDT and Aroclor 1254, are compared to the $\delta^{15} \mathrm{~N}$ in Citharichthys sordidus, significant negative relationships are seen (Fig. 4). Normalization of $\Sigma D D T$ and Aroclor 1254 to lipid content resulted in loss of significance for the relationship between $\Sigma D D T$ and $\delta^{15} \mathrm{~N}(r=0.22 ; F=0.98 ; p=0.35)$, but the relation was still significant for Aroclor $1254(r=0.47 ; F=5.2$; 
Table 6. Comparison of contaminant concentrations in invertebrates between sites. Concentrations are in $\mu \mathrm{g} \mathrm{kg}{ }^{-1}$ wet wt. SB: Santa Barbara; JWPCP: Los Angeles County Outfall. BD: below detection linit

\begin{tabular}{|c|c|c|c|c|c|}
\hline \multirow[t]{2}{*}{ Taxon } & \multirow{2}{*}{ Site } & \multirow[t]{2}{*}{$\Sigma D D T$} & \multicolumn{3}{|c|}{ Aroclors } \\
\hline & & & 1242 & 1254 & 1260 \\
\hline \multicolumn{6}{|l|}{ Polychaetes } \\
\hline \multirow[t]{2}{*}{ Glycerids } & SB & 807 & 150 & 815 & 461 \\
\hline & JWPCP & 7140 & 117 & 321 & 134 \\
\hline \multirow[t]{2}{*}{ Lumbrinerids } & SB & 469 & 164 & 321 & 100 \\
\hline & JWPCP & 22400 & $\mathrm{BD}$ & 511 & 5800 \\
\hline Nephthyiids & $S B$ & 266 & 116 & 97 & 601 \\
\hline Heteromastus sp. & JWPCP & 7030 & 95 & 185 & 70 \\
\hline Tharyx tesselata & JWPCP & 6090 & 376 & 164 & 20 \\
\hline \multirow[t]{2}{*}{ Pectinaria californica } & SB & 57 & 53 & 55 & 18 \\
\hline & JWPCP & 5270 & 1030 & 140 & 103 \\
\hline \multirow[t]{2}{*}{ Misc. polychaetes } & SB & 82 & 39 & 50 & 67 \\
\hline & JWPCP & 4260 & 471 & 140 & 89 \\
\hline \multicolumn{6}{|l|}{ Other invertebrates } \\
\hline \multirow[t]{2}{*}{ Nemerteans } & SB & 57 & 53 & 54 & 18 \\
\hline & JWPCP & 2980 & 215 & 91 & 224 \\
\hline Lytechinus pictus & SB & 23 & 26 & 41 & 24 \\
\hline Ophiuroids & SB & 23 & 10 & 12 & 9 \\
\hline
\end{tabular}

$p=0.03$ ). Such relationships would be consistent with the thesis that as individuals feed more in the outfall area their nitrogen content becomes isotopically lighter and they accumulate greater amounts of lipids and attain higher concentrations of the contaminants elevated in the outfall area.

Citharichthys sordidus was the only species that showed a relationship between $\delta^{13} \mathrm{C}$ and $\delta^{15} \mathrm{~N}(r=0.69$; $F=15.4 ; p=0.001$, such relationships are probably being obscured in the other species by body-size effects (Fig. 3). It is therefore not too surprising that relationships between isotope shifts and contaminant concentrations were not seen for the other 2 species. The lack of such relationships in the case of carbon isotopes may have been due to the effect variable lipid content of muscle had on $\delta^{13} \mathrm{C}$ (Table 8). Lipids in organisms are isotopically lighter in carbon than proteins and carbohydrates due to isotopic fractionation associated with lipid synthesis (DeNiro \& Epstein 1977). The $\delta D$ values of fish were not different between sites and the lack of correlation with contaminant concentrations was therefore not surprising. Although comparison of trophic level with contaminant concentrations in 3 species of fish did not produce clear evidence of a positive correlation, such comparisons over a larger range of trophic levels does reveal such trends. In Fig. 5 the plot of mean $\Sigma D D T$ and $\delta^{13} \mathrm{C}$ for outfall organisms reveals large increase of $\Sigma D D T$ with more positive values of $\delta^{13} \mathrm{C}$ over a wide range of trophic levels. A similar relationship exists for Aroclor 1254 (not shown). To make this comparison, invertebrates were assigned to either a detritivore-grazer group (Tharyx tesselata, Pectinaria californica, nephthyiids,
Lytechinus pictus and ophiuroids) or a carnivore group (glycerids, lumbrinerids) based on the known feeding habits of each taxon. Assignment of polychaete feeding habits was based mainly on the work of Fauchald \& Jumars (1979). In Fig. 5 the mean $\delta^{13} \mathrm{C}$ value increases by ca 0.7 to 1.0 and $\Sigma$ DDT concentrations by approximately an order of magnitude per trophic level. This relationship is based on chemical data that are not normalized to lipid content and the values for the fish species are only for the livers and not the whole fish. If it is assumed that there is as much as a 10 times lower concentration of $\Sigma D D T$ in whole fish there would still be a similar relationship, due to the logarithmic increase of $\Sigma$ DDT with each trophic step. The relationship in Fig. 5 is consistent with previous knowledge of the accumulation of lipophilic contaminants in higher trophic levels of food webs (see Murty 1986 for a discussion of the controversy surrounding the concept of food web magnification of chlorinated hydrocarbons).

\section{Behavior of contaminants in the food web}

Contaminant concentrations tended to be positively correlated in Zanillepis latipinnis but not in Microstomus pacificus. In Table 9 the correlations between lipid-normalized contaminant concentrations are presented for the 3 fish species. It can be seen that only a small number of significant correlations occur between chemicals in $M$. pacificus (6/55), a larger number (14/ 55) in Citharichthys stigmaeus and a much greater number in $Z$. latipinnis (47/55). This mirrors the trophic 
Table 7. Comparison of contaminant concentrations in livers between fish species and sites. Mean ( \pm SD). Values in $\mu g \mathrm{~kg}^{-1}$ wet wt

\begin{tabular}{|c|c|c|c|c|c|c|}
\hline \multirow[t]{2}{*}{ Variable } & \multirow[t]{2}{*}{ Site } & \multirow[b]{2}{*}{$\begin{array}{l}\text { Microstomus } \\
\text { pacificus }\end{array}$} & \multirow{2}{*}{$\begin{array}{l}\text { Species } \\
\text { Zaniolepis } \\
\text { latipinnis }\end{array}$} & \multirow[b]{2}{*}{$\begin{array}{l}\text { Citharichthys } \\
\text { sordidus }\end{array}$} & \multicolumn{2}{|c|}{ Significant differences } \\
\hline & & & & & Site & Species \\
\hline $\mathrm{HCB}^{\mathrm{a}}$ & $\begin{array}{l}\text { SB } \\
\text { JWPCP }\end{array}$ & $\begin{array}{l}54.4 \pm 64.7(4)^{\mathrm{b}} \\
6.02 \pm 4.34(19)\end{array}$ & $\begin{array}{l}10.9 \pm 10.0(5) \\
3.86 \pm 3.31(20)\end{array}$ & $\begin{array}{l}37.0 \pm 38.9(4) \\
34.0 \pm 110.0(18)\end{array}$ & & \\
\hline$\Sigma \mathrm{DDT}$ & $\begin{array}{l}\text { SB } \\
\text { JWPCP }\end{array}$ & $\begin{array}{c}2040 \pm 2020(4) \\
23800 \pm 9400(19)\end{array}$ & $\begin{array}{c}3900 \pm 2840(5) \\
42400 \pm 12900(20)\end{array}$ & $\begin{array}{c}1630 \pm 548(4) \\
60000 \pm 39100(21)\end{array}$ & $\cdots$ & \\
\hline Aroclor 1242 & $\begin{array}{l}\text { SB } \\
\text { JWPCP }\end{array}$ & $\begin{array}{r}1280 \pm 1550(4) \\
653 \pm 182(19)\end{array}$ & $\begin{array}{c}165 \pm 146(4) \\
1080 \pm 476(20)\end{array}$ & $\begin{array}{c}264 \pm 47(4) \\
1300 \pm 1280(21)\end{array}$ & & $\cdot$ \\
\hline Aroclor 1254 & $\begin{array}{l}\text { SB } \\
\text { JWPCP }\end{array}$ & $\begin{array}{l}1260 \pm 1460(4) \\
1330 \pm 470(19)\end{array}$ & $\begin{array}{c}388 \pm 138(4) \\
6550 \pm 3610(20)\end{array}$ & $\begin{aligned} 337 & \pm 218(4) \\
9200 & \pm 11200(21)\end{aligned}$ & $\cdot$ & $\cdots$ \\
\hline Aroclor 1260 & $\begin{array}{l}\text { SB } \\
\text { JWPCP }\end{array}$ & $\begin{array}{r}2720 \pm 2700(4) \\
876 \pm 781(19)\end{array}$ & $\begin{array}{l}1630 \pm 933(4) \\
2010 \pm 1390(20)\end{array}$ & $\begin{array}{l}5320 \pm 2040(4) \\
3920 \pm 3000(21)\end{array}$ & $\cdots$ & $\cdots$ \\
\hline $\begin{array}{r}\text { Phthalates } \\
\text { Dimethyl }\end{array}$ & $\begin{array}{l}\text { SB } \\
\text { JWPCP }\end{array}$ & $\begin{array}{c}169 \pm 236(4) \\
11.4 \pm 17.1(19)\end{array}$ & $\begin{array}{l}50.8 \pm 39.0(4) \\
13.1 \pm 12.2(19)\end{array}$ & $\begin{array}{l}131 \pm 169(4) \\
238 \pm 858(18)\end{array}$ & & \\
\hline Diethyl & $\begin{array}{l}\mathrm{SB} \\
\text { JWPCP }\end{array}$ & $\begin{array}{c}365 \pm 324(4) \\
46.0 \pm 37.9(19)\end{array}$ & $\begin{array}{c}189 \pm 128(4) \\
29.2 \pm 21.7(20)\end{array}$ & $\begin{array}{l}257 \pm 187(4) \\
200 \pm 661(18)\end{array}$ & & \\
\hline Dibutyl & $\begin{array}{l}\mathrm{SB} \\
\mathrm{JWPCP}\end{array}$ & $\begin{array}{c}186 \pm 113(4) \\
17.4 \pm 12.2(19)\end{array}$ & $\begin{array}{l}20.0 \pm 16.8(4) \\
11.1 \pm 8.4(20)\end{array}$ & $\begin{array}{l}28.2 \pm 24.4(4) \\
55.4 \pm 83.7(18)\end{array}$ & $\because$ & $\cdots$ \\
\hline Butyl benzyl & $\begin{array}{l}\text { SB } \\
\text { JWPCP }\end{array}$ & $\begin{array}{r}39.0 \pm 47.5(4) \\
3.4 \pm 4.0(19)\end{array}$ & $\begin{array}{l}2.6 \pm 2.0(4) \\
3.2 \pm 1.6(20)\end{array}$ & $\begin{array}{r}28.8 \pm 35.3(4) \\
6.3 \pm 4.0(18)\end{array}$ & $\cdots$ & $\cdots$ \\
\hline Dioctyl & $\begin{array}{l}\text { SB } \\
\text { JWPCP }\end{array}$ & $\begin{array}{l}531 \pm 731(4) \\
33.2 \pm 12.2(19)\end{array}$ & $\begin{array}{l}42.9 \pm 20.7(4) \\
66.8 \pm 33.8(20)\end{array}$ & $\begin{array}{c}188 \pm 301(4) \\
10.7 \pm 78.7(18)\end{array}$ & $\cdots$ & $\cdots$ \\
\hline Bis(-2 ethylhexyl) & $\begin{array}{l}\text { SB } \\
\text { JWPCP }\end{array}$ & $\begin{array}{c}173 \pm 154(4) \\
46.4 \pm 46.3(19)\end{array}$ & $\begin{array}{l}54.3 \pm 28.5(4) \\
40.7 \pm 23.9(20)\end{array}$ & $\begin{array}{c}254 \pm 406(4) \\
83.1 \pm 74.5(18)\end{array}$ & $\cdots$ & $\cdot$ \\
\hline EPhthalates & $\begin{array}{l}\text { SB } \\
\text { JWPCP }\end{array}$ & $\begin{array}{c}1460 \pm 823 \\
158 \pm 84\end{array}$ & $\begin{array}{l}360 \pm 197 \\
164 \pm 72.2\end{array}$ & $\begin{array}{l}890 \pm 1112 \\
751 \pm 1564\end{array}$ & $\cdot$ & \\
\hline $\begin{array}{l}{ }^{\mathrm{a}} \mathrm{HCB} \text { : hexachlorob } \\
\mathrm{b}^{\mathrm{b}} \text { Sample size } \\
{ }^{\circ} p<0.05,{ }^{\cdots} p<0.0\end{array}$ & $\begin{array}{l}\text { enzene } \\
1, \cdots p\end{array}$ & by ANOVA & & & & \\
\hline
\end{tabular}

order of these species suggested by the carbon and nitrogen isotope data (Fig. 2) and the $\mathrm{Cs} / \mathrm{K}$ data (Table 4). The cause of this phenomenon is unclear.

A related trend is that the organic compounds measured in Zaniolepis latipinnis tend to vary similarly between individuals when the compounds have a similar $\mathrm{K}_{\text {ow. }}$ ( $\mathrm{K}_{\text {ow }}$ is the $n$-octanol/water partitioning coefficient of a compound.) This tendency is illustrated in Fig. 6, where the ratio of $K_{\text {ow }}$ for pairwise comparison of compounds is weakly correlated $(p=0.047)$ to their correlation coefficients among individuals collected at JWPCP. This relationship was not evident in Citharichthys stigmaeus or Microstomus pacificus.

\section{DISCUSSION}

The lack of site differences for $\delta D$ for all 3 species of fish was surprising since Rau et al. (1981) had found differences between the JWPCP outfall area and the reference area near Ventura (southeast of Santa Barbara) for Microstomus pacificus and the shrimp Sicyonia ingentis, based on values for 5 specimens from each site. Our $\delta \mathrm{D}$ values for fish from both sites are very similar to values Rau et al, obtained in 1980 for $M$. pacificus from Ventura, while the values they obtained for this species from the JWPCP area were about $-58 \%$, much more closely aligned with our values for sewage particulate matter. This difference indicates a change in the organic matter utilized by the food web in the outfall sediments between 1979 and 1983, becoming more marine in character. During the 1970's and the early 1980's large reductions in mass-emission rates of suspended solids were achieved through improvements in the sewage treatment facilities by the County of Los Angeles (Stull et al. 1986a). Such drastic reductions have probably affected the balance of terrestrial and marine-derived organic matter in these 


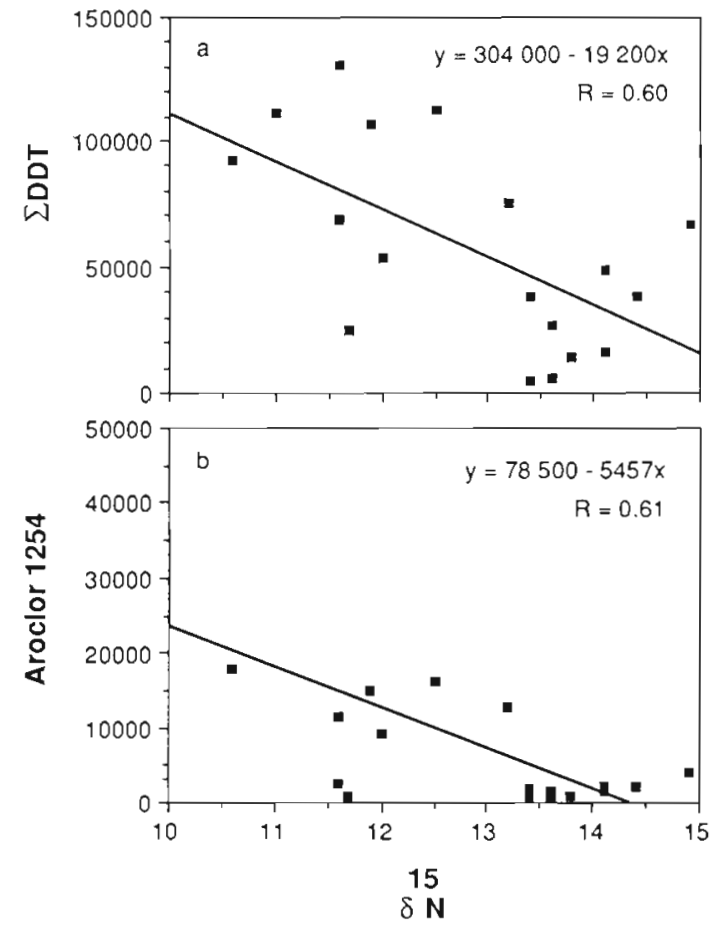

Fig. 4. Citharichthys sordidus. Relationships between $\delta^{15} \mathrm{~N}$ in flesh and concentrations of contaminants in livers (wet wt basis) of individuals from the JWPCP outfall area (a) $\Sigma D D T$ and $\delta^{15} \mathrm{~N}$; (b) Aroclor 1254 and $\delta^{15} \mathrm{~N}$

Table 8. Microstomus pacificus. Relative abundances of stable isotopes in muscle tissue from JWPCP fish before and after extraction of lipids

\begin{tabular}{|clccc|}
\hline \multirow{2}{*}{ Sample } & \multicolumn{1}{c}{ Material } & $\delta^{13} \mathrm{C}$ & $\delta^{15} \mathrm{~N}$ & $\delta \mathrm{D}$ \\
\hline \multirow{6}{*}{29618} & Original sample & -21.7 & 9.3 & -150 \\
& Re-run & -19.7 & 9.3 & -102 \\
& Extracted lipids & -23.3 & - & -160 \\
& Lipid-free fish & -18.0 & 9.4 & -85 \\
& Original sample & -20.6 & 14.1 & -116 \\
& Re-run & -20.1 & 16.2 & -114 \\
& Extracted lipids & -23.4 & - & -157 \\
& Lipid free fish & -17.2 & 15.4 & -72 \\
\hline
\end{tabular}

sediments. Also in 1983 very severe storms disturbed sediments to depths greater than $60 \mathrm{~m}$ and it is not known what effect this may have had on the relative availability of sewage and endogenous organic matter in these sediments previous to our collections later that year.

There is relatively little information available on concentrations of neutral organic contaminants in marine invertebrates from the Los Angeles area. Concentrations of $\Sigma D D T$ from 100 to $2100 \mu \mathrm{g} \mathrm{kg}^{-1}$ wet wt have been reported in various whole crabs near the JWPCP outfall (Young \& McDermott 1974). Our values for

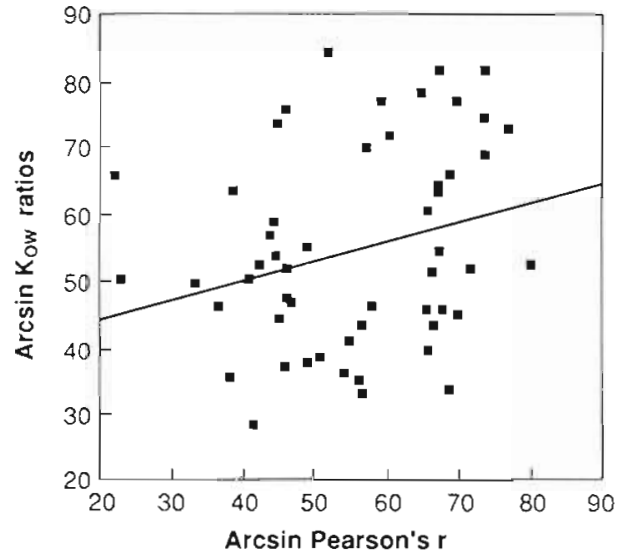

Fig. 5. Zaniolepis latipinnis. Relation between correlation coefficients (Pearson's $x$ ) for pairs of chemicals on a lipidweight basis and the ratios of their $n$-octanol/water partitioning coefficients $\left(\log \mathrm{K}_{\mathrm{ow}}\right)$

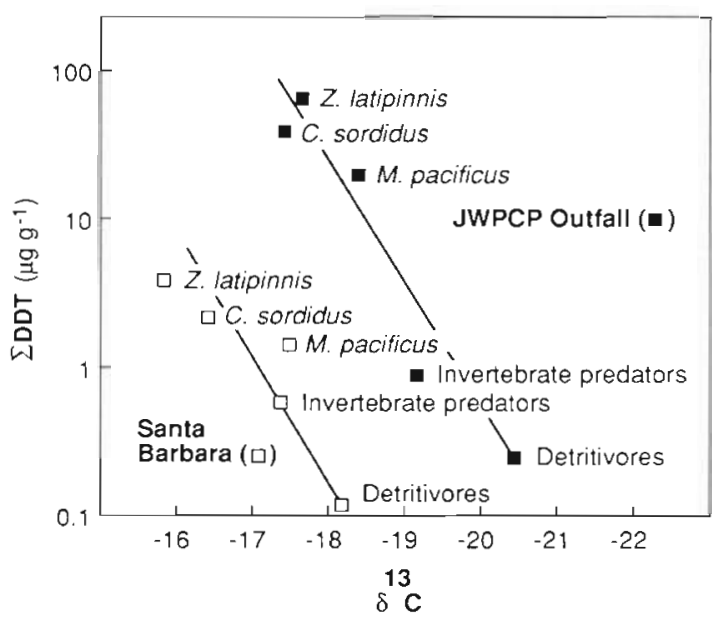

Fig. 6. Relation between trophic level, $\delta^{13} \mathrm{C}$, and DDT concentrations in invertebrates and fish from the 2 study sites in the Southern California Bight

$\mathrm{DDT}$ in infaunal invertebrates range from ca 4000 to $22000 \mu \mathrm{g} \mathrm{kg}^{-1}$ wet wt. This difference may be due partly to differences in exposure or partly to different methods of estimating chemical recovery (Gossett pers. comm.). Also our determinations were made mainly on infaunal invertebrates and earlier measurements were made on epifaunal invertebrates.

Concentrations of $\Sigma D D T$ have been reported from 19000 to $250000 \mu \mathrm{g} \mathrm{kg}^{-1}$ wet wt in the livers of Microstomus pacificus (McDermott \& Heesen 1975, Young \& Heesen 1976, Gossett et al. 1982) and $125000 \mu \mathrm{g} \mathrm{kg}^{-1}$ wet wt in the liver of Citharichthys sordidus (Gossett et al. 1982). Our mean values for $M$. pacificus are in the low end of the range previously reported and for $C$. sordidus, approximately half the previously published concentrations. Since our concentrations are corrected 
Table 9. Pearson correlation coefficients between lipid-normalized concentrations of pairs of chemical contaminants in livers of 3 fish species collected near the JWPCP outfall. Significant correlations are underlined. Numbers refer to appropriate aroclors. Abbreviations: HCB, hexachlorobenzone; phthalic acid esters: DMP, dimethyl; DEP, diethyl; DBT, dibutyl; BBT, butylbenzyl; DOP doctyl; DEPH, bis( -2 ethylhexyl)

\begin{tabular}{|c|c|c|c|c|c|c|c|c|c|c|c|}
\hline & 1242 & 1254 & 1260 & $\Sigma D D T$ & $\mathrm{HCB}$ & $D M P$ & DEP & DBT & $\mathrm{BBT}$ & DOP & DEHP \\
\hline \multicolumn{12}{|c|}{ A. Microstomus pacificus } \\
\hline 1242 & 1.0 & & & & & & & & & & \\
\hline 1254 & 0.24 & 1.0 & & & & & & & & & \\
\hline 1260 & 0.32 & 0.28 & 1.0 & & & & & & & & \\
\hline DDT & -0.16 & 0.67 & -0.05 & 1.0 & & & & & & & \\
\hline $\mathrm{HCB}$ & 0.55 & -0.10 & 0.55 & -0.34 & 1.0 & & & & & & \\
\hline DMP & $\overline{0.20}$ & -0.17 & $\overline{0.19}$ & -0.38 & $\underline{0.51}$ & 1.0 & & & & & \\
\hline DEP & -0.10 & -0.41 & -0.27 & -0.32 & $\overline{0.21}$ & 0.39 & 1.0 & & & & \\
\hline DBT & -0.22 & -0.03 & -0.26 & 0.41 & -0.20 & -0.25 & 0.45 & 1.0 & & & \\
\hline $\mathrm{BBT}$ & -0.15 & -0.28 & -0.09 & -0.19 & 0.35 & 0.31 & 0.70 & -0.11 & 1.0 & & \\
\hline DOP & 0.27 & 0.23 & 0.38 & 0.09 & 0.32 & 0.68 & 0.03 & 0.13 & -0.04 & 1.0 & \\
\hline DEHP & 0.37 & 0.30 & 0.39 & 0.32 & 0.30 & $\overline{0.41}$ & 0.05 & 0.41 & 0.13 & 0.69 & 1.0 \\
\hline \multicolumn{12}{|c|}{ B. Citharichthys sordidus } \\
\hline 1242 & 1.0 & & & & & & & & & & \\
\hline 1254 & -0.07 & 1.0 & & & & & & & & & \\
\hline 1260 & 0.38 & -0.10 & 1.0 & & & & & & & & \\
\hline DDT & 0.37 & 0.45 & 0.31 & 1.0 & & & & & & & \\
\hline $\mathrm{HCB}$ & -0.07 & $-\overline{0.12}$ & 0.24 & -0.08 & 1.0 & & & & & & \\
\hline DMP & -0.18 & -0.16 & 0.26 & -0.20 & 0.96 & 1.0 & & & & & \\
\hline DEP & 0.03 & -0.22 & 0.36 & 0.07 & $\overline{0.94}$ & $\underline{0.87}$ & 1.0 & & & & \\
\hline DBT & 0.02 & -0.03 & 0.30 & 0.57. & $\overline{0.11}$ & $\overline{0.18}$ & 0.21 & 1.0 & & & \\
\hline $\mathrm{BBT}$ & 0.46 & 0.22 & 0.40 & $\overline{0.78}$ & 0.25 & 0.03 & 0.42 & 0.36 & 1.0 & & \\
\hline DOP & 0.45 & 0.48 & 0.38 & $\overline{0.89}$ & 0.11 & -0.07 & 0.25 & 0.38 & 0.95 & 1.0 & \\
\hline DEHP & 0.63 & $\overline{0.15}$ & $\underline{0.70}$ & $\overrightarrow{0.80}$ & 0.17 & 0.05 & 0.33 & $\underline{0.50}$ & $\overline{0.76}$ & 0.77 & 1.0 \\
\hline \multicolumn{12}{|c|}{ C. Zaniolepis latipinnis } \\
\hline 1242 & 1.0 & & & & & & & & & & \\
\hline 1254 & 0.95 & 1.0 & & & & & & & & & \\
\hline 1260 & $\overline{0.85}$ & $\underline{0.92}$ & 1.0 & & & & & & & & \\
\hline DDT & $\overline{0.85}$ & $\overline{0.92}$ & 0.85 & 1.0 & & & & & & & \\
\hline $\mathrm{HCB}$ & $\overline{0.76}$ & $\overline{0.62}$ & $\overline{0.71}$ & 0.50 & 1.0 & & & & & & \\
\hline DMP & $\overline{0.57}$ & $\overrightarrow{0.66}$ & $\overline{0.70}$ & $\overline{0.5 \underline{2}}$ & 0.38 & 1.0 & & & & & \\
\hline DEP & $\overline{0.52}$ & $0.5 \overline{0}$ & $\overline{0.67}$ & $0.6 \overline{7}$ & 0.51 & 0.48 & 1.0 & & & & \\
\hline DBT & $\overline{0.86}$ & $\overline{0.84}$ & $\overline{0.83}$ & $\overline{0.83}$ & $\overline{0.70}$ & $\overline{0.49}$ & 0.74 & 1.0 & & & \\
\hline BBT & $\overline{0.82}$ & $\overline{0.88}$ & 0.87 & $\overline{0.92}$ & $\overline{0.52}$ & $\overline{0.51}$ & $\overline{0.72}$ & 0.88 & 1.0 & & \\
\hline DOP & $\overline{0.84}$ & $\overline{0.85}$ & $\overline{0.83}$ & $\overline{0.90}$ & $\overline{0.57}$ & $\overline{0.44}$ & $\overline{0.69}$ & 0.87 & 0.97 & 1.0 & \\
\hline DEHP & $\overline{0.49}$ & $\overline{0.43}$ & $\overline{0.35}$ & $\overline{0.45}$ & $\overline{0.30}$ & 0.15 & $\overline{0.14}$ & $\overline{0.39}$ & $\overline{0.52}$ & 0.60 & 1.0 \\
\hline
\end{tabular}

for recovery of the internal standard and those from previous studies have not been so corrected (Gossett pers. comm.), the actual differences are greater than the data indicate. It should again be emphasized that contaminated sediments in the outfall area have been covered with a layer of less contaminated material in recent years (Stull et al. 1986a). This could have resulted in less of the contaminants entering the food web at the time of this study and could partially explain the observed concentration differences between this and previous studies.

The correlation between body weight and $\delta^{15} \mathrm{~N}$ and Microstomus pacificus noted here was also seen by Rau et al. (1981), and the slope of their relation was identical to ours (0.06) (Fig. 3a). Rau et al. interpreted the $\delta^{15} \mathrm{~N}$ shifts with size to indicate a metabolic effect, with more ${ }^{15} \mathrm{~N}$ remaining in the fish with age. One would expect this metabolic effect to be a fairly general phenomenon, occurring in many fishes. We did not. however, find this same relationship in the other 2 species of fish, which indicates that the $\delta^{15} \mathrm{~N}$ trend in this species may be more related to ecological factors. Rau et al. (1981) found a $4.7 \%$ difference in $\delta^{15} \mathrm{~N}$ between fish from Ventura and the JWPCP area in 1979, while the difference we found between samples taken in similar areas in 1983 was $2.4 \%$. There were no significant differences in $\delta^{15} \mathrm{~N}$ between $M$. pacificus collected in the 2 studies from near the JWPCP ( $p=$ 0.23). Mean $\delta^{13} \mathrm{C}$ in this species from near the JWPCP were nearly identical from the 2 studies. While we 
ascribe size-related differences in $\delta^{15} \mathrm{~N}$ in $M$. pacificus mainly to changing diet with size rather than an isotope effect due to metabolism, the specimens analysed from Santa Barbara were much smaller (ca $8 \mathrm{~g}$ each) than those from the JWPCP outfall area (from 42 to $110 \mathrm{~g}$ each). Therefore, if there were really a relationship between size and $\delta^{15} \mathrm{~N}$ due to an isotope effect, the use of larger fish from the control area would have resulted in an even greater difference in $\delta^{15} \mathrm{~N}$ than observed.

The local movement of Citharichthys sordidus in and out of the outfall area is a behavior pattern consistent with the ecological data that indicate there is not a strong attraction of this species for the outfall area (Cross et al. 1985). This behavior pattern would be expected to result in both a greater accumulation of those contaminants that were elevated near the outfall and in isotope ratio shifts that were different in the outfall area in some individuals. Therefore, it might be expected that contaminant concentrations and shifts in stable isotope ratios might be correlated. Indeed, Aroclor 1254 and IDDT are elevated in these species relative to the $\mathrm{SB}$ reference site (Table 7 ) and their concentrations correlate with $\delta^{15} \mathrm{~N}$ (Fig. 4). An alternative explanation is that the switch from partly benthic to wholly pelagic prey in larger specimens (Allen 1982) would result in greater contaminant concentrations along with isotopic shifts toward lighter carbon and nitrogen. However, size did not correlate with either of these measures in this species.

It has now been well established that $\delta^{13} \mathrm{C}$ increases slightly with each trophic transfer (DeNiro \& Epstein 1978, Teeri \& Schoeller 1979, Stephenson et al. 1986). This phenomenon has been utilized to interpret the structure of complex food webs where it is not entirely clear that the trophic level assignments should be for animals that feed on organisms from various trophic levels (Haines \& Montague 1979, McConnaughey \& McRoy 1979a, b, Rau et al. 1983). Data presented here indicate that a combination of $\delta^{13} \mathrm{C}$ and $\delta^{15} \mathrm{~N}$ predicts trophic level better than $\mathrm{Cs} / \mathrm{K}$. However, we used about 20 of each species for the isotope ratio analyses and only 5 of each species for the $C s$ and $K$ analyses. Perhaps with more $\mathrm{Cs} / \mathrm{K}$ values clearer separations between species, such as those observed from the isotope ratio data, would be evident.

The data support the following conclusions: (1) the 3 species of fish collected in the outfall area obtained about 15 to $20 \%$ of their carbon and nitrogen from sewage and this varied little between species; (2) carbon and nitrogen became isotopically heavier and $\mathrm{Cs} / \mathrm{K}$ increased in the 3 species in the order of: Microstomus pacificus, Citharichthys sordidus and Zaniolepis latipinnis, which suggests strongly that trophic levels increase in this order $(3) M$. pacificus, a species that apparently occupies a lower trophic level than the other 2 species, accumulated the lowest concentrations of LDDT and PCBs; (4) Aroclor 1254 and EDDT bioaccumulate through the food web, from invertebrate detritus feeders to predatory fish, although for EDDT in fish this may related to lipid content; (5) contaminants tend to correlate positively between individuals of a fish species with increasing trophic level, and the reason for this remains unclear.

Acknowledgements. We are grateful to I. Haydock of the Los Angeles County Sanitation District for making the 'Sea-SDee' available for sampling and for the sample of sewage particulate matter. Willard Bascom, director of the Southern California Coastal Water Research Project (SCCWRP) at the time of this study, graciously made laboratory space available for processing field samples. Jeff Cross of SCCWRP was particularly helpful in our field work. Don Baumgartner, Bruce Boese and Henry Lee of EPA's Marine Laboratory, Newport, Oregon have given us support and many helpful suggestions. We thank D. Young, from the same laboratory, for invaluable discussions of the Cs and $\mathrm{K}$ data. This work was performed under the auspices of the U.S. Department of Energy by the Lawrence Livermore National Laboratory (LLNL) under Contract No. W-7405-ENG-48. Although the research described in this paper was funded by the U.S. Environmental Protection Agency through Interagency Agreement AD-89-E2A267 to LLNL, it has not been subjected to the Agency's required peer and policy review and therefore does not necessarily reflect the views of the Agency

\section{LITERATURE CITED}

Allen, M. J. (1977). Pollution related alterations of southern California demersal fish communities. Cal-Neva Wildlife Trans. 1977: 103-107

Allen, M. J. (1982). Functional structure of soft-bottom communities of the Southern California Shelf. Ph. D. dissertation, Univ. of California, San Diego

Cross, J. N. (1985). Fin erosion among fishes collected near a southern California municipal waste outfall (1971-82). Fish Bull. U. S. 83: 195-206

Cross, J. N., Roney, J., Kleppel, G. S. (1985). Fish food habits along a pollution gradient. Calif. Fish Game 71: 28-39

DeNiro, M. J., Epstein, S. (1977). Mechanism of carbon isotope fractionation associated with lipid synthesis. Science 197: 261-263

DeNiro, M. J., Epstein, S. (1978). Influence of diet on the distribution of carbon isotopes in animals. Geochim. Cosmochim. Acta 42: 495-506

DeNiro, M. J., Epstein, S. (1980). Influence of diet on the distribution of nitrogen isotopes in animals. Geochim. Cosmochim. Acta 45: 351-353

Eganhouse, R. P., Kaplan, I. R. (1982). Extractable organic matter in municipal wastewater5. 1. Petroleum hydrocarbons: temporal variations and mass emission rates to the ocean. Environ. Sci. Technol. 16: 180-186

Estep, M. F., Dabrowski, H. (1980). Tracing food webs with stable hydrogen isotopes. Science 209: 1537-1538

Estep, M. F., Hoering, T C. (1980). Biogeochemistry of the stable hydrogen isotopes. Geochim. Cosmochim. Acta 44: 1197-1206

Fauchald, K., Jumars, P. A. (1979). The diet of polychaete worms: a study of polychaete feeding guilds. Oceanogr. mar. Biol. A. Rev. 17: 193-284 
Gossett, R. W., Brown, D. A., Young, D. R. (1982). Predicting the bioaccumulation and toxicity of organic compounds. So. Calif. Coast. Water Res. Proj., Ann. Rep. Long Beach, p. $149-156$

Haines, E. B., Montague, C. L. (1979). Food sources of estuarine invertebrates analysed using ${ }^{12} \mathrm{C} /{ }^{13} \mathrm{C}$ ratios. Ecology 60: 48-56

McConnaughey, T., McRoy, C. P. (1979a). Food web structure and the fractionation of carbon isotopes in the Bering Sea. Mar. Biol. 53: 257-262

McConnaughey, T., McRoy, C. P. $(1979 b) .{ }^{13} \mathrm{C}$ label identifies eel grass, Zostera marina, carbon in an Alaskan estuarine food web. Mar. Biol. 53: 263-263

McDermott, D. J., Heesen, T. C. (1975). DDT and PCB in Dover sole around outfalls. So. Calif. Coast. Water Res. Proj., Ann. Rep., Long Beach, p. 117-121

Minagawa, M., Wada, E. (1984). Stepwise enrichment of ${ }^{15} \mathrm{~N}$ along food chains: further evidence and the relation between $\delta^{15} \mathrm{~N}$ and animal age. Geochim. Cosmochim Acta 48: $1135-1140$

Murty, A. S. (1986). Toxicity of pesticides to fish. Vol. 1. CRC Press, Boca Raton, Florida

Myers, E. P. (1974). The concentration and isotopic composition of carbon in marine sediments affected by sewage discharge. Ph. D. dissertation, Calif. Inst. Technol., Pasadena

Ozretich, R. J., Schroeder, W. P. (1986). Determination of neutral organic priority pollutants in marine sediment, tissue and reference material utilizing bonded phase sorbent. Analyt. Chem. 58: 2041-2047

Pearson, T. H., Rosenberg, R. (1978). Macorbenthic succession in relation to organic enrichment and pollution of the marine environment. Oceanogr. mar. Biol. A. Rev. 16: 229-311

Rau, G. H., Mearns, A. J., Young, D. R., Olson, R. J., Schafer, H. A., Kaplan, I. R. (1983). Animal ${ }^{13} \mathrm{C} /{ }^{12} \mathrm{C}$ correlates with trophic level in pelagic food webs. Ecology 64: 1314-1318

Rau, G. H., Sweeney, R. E., Kaplan, I. R., Mearns, A. J., Young, D. R. (1981). Differences in animal ${ }^{13} \mathrm{C},{ }^{15} \mathrm{~N}$ and $\mathrm{D}$ abundance between a polluted and unpolluted coastal site: Likely indicators of sewage uptake by a marine food web. Estuar. coast. Shelf Sci. 13: 701-707

SAS (1985). SAS user's guide: statistics, version 5 edn. SAS Institute, Inc., Cary

SCCWRP (1973). The ecology of the Southern California Bight: implications for water quality management. Rep. TR104, So. Calif. Coast. Water Res. Proj., El Segundo

Schafer, H. R. (1984). Characteristics of municipal waste water. So. Calif. Coast. Water Res. Proj., Biennial. Rep., 1983-1984, Long Beach, p. 11-19

Smith, R. W., Greene, C. S. (1976). Biological communities near submarine outfalls. J. Water Pollut. Control. Fed. 4: $1894-1912$

Spies, R. B. (1984). Benthic-pelagic coupling in sewage affected marine ecosystems. Mar. Environ. Res. 13: $195-230$

Spies, R. B., DesMarais, D. J. (1983). Natural isotope study of trophic enrichment of benthic communities by petroleum seepage. Mar. Biol. 73:67-71

Stanley, S. O., Pearson, T. H., Brown, C. M. (1978). Marine microbial ecosystems and the degradation of organic pol-

This article was submitted to the editor lutants. In: Chater, K. W. A., Somerville, H. J. (eds.) The oil industry and microbial ecosystems. Institute of Petroleum, London, p. 60-79

Stephenson, R. L., Tan, F. C., Mann, K. H. (1986). Use of stable carbon isotope ratios to compare plant material and potential consumers in a seagrass bed and kelp bed in Nova Scotia, Canada. Mar. Ecol. Prog. Ser. 30: 1-7

Stuermer, D. H., Peters, K. E., Kaplan, I. R. (1978). Source indicators of humic substances and protokerogen. Stable isotope ratios, elemental compositions and electron spin resonance spectra. Geochim. Cosmochim. Acta 42 989-997

Stull, J. K., Baird, R. B., Heesen, T. C. (1986a). Marine sediment core profiles of trace constituents offshore of a deep wastewater outfall. J. Water Pollut. Control Fed. 10: 985-991

Stull, J. K., Haydock, C. I., Smith, R. W., Montagne, D. E. (1986b). Long-term changes in the benthic community on the coastal shelf of Palos Verdes, Southern California. Mar. Biol. 91: 539-551

Sweeney, R. E., Kalil, E. K., Kaplan, I. R. (1980). Characterization of domestic and industrial sewage in southern Califor nia coastal marine sediments using nitrogen, carbon, sulfur and uranium tracers. Mar. Environ. Res. 3: 225-243

Sweeney, R. E., Kaplan, I. R. (1980). Tracing flocculent industrial and domestic sewage transport on San Pedro Shelf, southern California, by nitrogen and sulfur isotope ratios. Mar. Environ. Res. 3: 215-224

Teeri, J. A., Schoeller, D. A. $(1979) . \delta^{13} \mathrm{C}$ values of an herbivore and the ratio of $\mathrm{C}_{3}$ and $\mathrm{C}_{4}$ plant carbon in its diet. Oecologia (Berl.) 39: 197-200

Venkatesan, M. I., Brenner, S., Ruth, E., Bonilla, E., Kaplan, I R. (1980). Hydrocarbons in age-dated sediment cores from two basins in the southern California Bight. Geochim. Cosmochim. Acta 44: 789-802

Wada, W., Kadonaga, T., Matsuo, S. (1975). ${ }^{15} \mathrm{~N}$ abundance in nitrogen of naturally occurring substances and global assessment of denitrification from isotopic viewpoint Geochem. J. 9: 134-148

Word, J. Q., Mearns, A. J. (1978). The 60-m control survey. So Calif. Coast. Water Res. Proj., Ann. Rep., Long Beach, p. $41-56$

Word, J. Q., Striplin, P. L. (1980). Benthic microcrustacea and echinoderms on the Palos Verdes Shelf. So. Calif. Coast Water Res. Proj. Ann. Rep., Long Beach, p. 13-20

Young, D. R. (1970). The distribution of cesium, rubidium, and potassium in the quasi-marine ecosystem of the Salton Sea. Ph. D. dissertation, Univ. of California, San Diego

Young, D. R., Gossett, R. (1980). Chlorinated benzenes in sediments and organisms. So. Calif. Coast. Water Res Proj., Ann. Rep., Long Beach, p. 181-195

Young, D. R., Heesen, T. C. (1976). Inputs of chlorinated benzenes. So. Calif. Coast. Water Res. Proj., Ann. Rep. Long Beach, p. 31-37

Young, D. R., McDermott, D. J. (1974). DDT in benthic fishes So. Calif. Coast. Water Res. Proj., Ann. Rep., Long Beach p. $113-115$

Young, D. R., Mearns, A. J., Jan, T.-K., Heesen, T. C., Moore M., Eganhouse, R. P., Hershelman, G. P., Gossett, R (1980). Trophic structure and pollutant concentrations in marine ecosystems of Southern California. Calif. Coop Oceanic Fish. Invest. Prog. Rep. 21: 197-206

Manuscript first received: January 16, 1987

Revised version accepted: February 23, 1989 